\title{
Biodegradability of Bioplastic from Oil Palm Empty Fruit Bunch
}

\author{
Anggun Rahman ${ }^{\mathrm{a}}$, Khaswar Syamsu ${ }^{\mathrm{b}}$, and Isroi ${ }^{\mathrm{c}}$ \\ aProgram Study of Natural Resources and Environmental Management, Bogor Agricultural University, Bogor, 16680, \\ Indonesia \\ ${ }^{b}$ Department of Agroindustrial Technology, Bogor Agricultural University, Bogor, 16680, Indonesia \\ ${ }^{\mathrm{c}}$ Indonesian Research Institute for Biotechnology and Bioindustry, Bogor, 16680, Indonesia
}

\section{Article Info:}

Received: 26 - 12 - 2017

Accepted: 17 - $05-2018$

\section{Keywords:}

Biodegradation, bioplastic, natural inoculums.

\section{Corresponding Author:}

Anggun Rahman

Program Study of Natural

Resources and Environmental

Management, Bogor

Agricultural University, Bogor;

Email:

anggunrhmn26@gmail.com

\begin{abstract}
Biodegradation of the bioplastic composite based on cellulose from oil palm empty fruit bunches was investigated in this study. Microbes consortium from landfill soil collected from top soil were used as the inoculums for the biodegradation process. Biodeg-radation test of the bioplastic from oil palm empty fruit bunch samples compared with oxodegradation and conventional plastic samples were conducted in the glass jar. The biodegradation rate was evaluated from $\mathrm{CO}_{2}$ generated from the biodegradation process and absorbed by $0.1 \mathrm{~N}$ sodium hydroxide solutions. The generated $\mathrm{CO}_{2}$ was titrated with $0.1 \mathrm{~N} \mathrm{HCl}$ and using phenol-phthalein (PP) followed by methyl oranges indicator. The results showed that the highest $\mathrm{CO}_{2}$ production on landfill soil indicating the highest rate of biodegradation was found on bioplastic from oil palm empty fruit bunch followed by oxodegradable plastic and conventional plastic. The rate of biodegradation for bioplastic from oil palm empty fruit bunch, oxodegradable plastic and conven-tional plastic were 0.067, 0.052 and $0.000 \mathrm{mg} \mathrm{CO} /$ day, respectively.
\end{abstract}

How to cite (CSE Style $8^{\text {th }}$ Edition):

Rahman A, Syamsu K, Isroi. 2019. Biodegradability of Bioplastic from Oil Palm Empty Fruit Bunch. JPSL 9(2): $259-264$. http://dx.doi.org/10.29244/jps1.9.2.259-264.

\section{INTRODUCTION}

Plastic are widely used as packaging and many other applications and continues to increase. Plastic packaging has several advantages, namely durable, light, inert, not rusty, thermoplastic, and able to be colored. The amount of plastic waste is increasing year by year. Recycle and reuse of the plastic waste capacity are not as much as increasing the plastic waste. The World production of plastics was 311 million tonnes in 2014. Plastics demand for Asia is $16 \%$ from the total production (260 million tonnes) of plastics materials in the world (Plastics Europe 2015). In 2014, 25.8 million tones of post-consumer plastics waste ended up in the official waste streams; $69.2 \%$ was recovered through recycling and energy recovery processes while $30.8 \%$ still end up to landfill. Within the different plastic applications, plastic packaging reached the highest recycling rate $(39.5 \%)$ and repre-sented more than $80 \%$ of the total recycled quantities (Plastics Europe 2015). This statistic highlights the need for a renewable, all natural replacement for pe-troleum based plastics (DiGregorio 2009).

One of the problems of the petroleum based plastic is very difficult to be bio-degraded in nature and causes environmental pollution (Isroi et al. 2017). Its chemical structure which is a high molecular weight and has a strong bonding chain, makes this plastic taking a very long time to decompose in nature and become an environmental problem such as landslides and floods. The non-degradable synthetic plastic ac-cumulates in the environment, where they create problems for wildlife and their habitats as well as for human life. Toxic 
plastic particles in soil can kill de-composer organisms, such as worms, and can result in a decrease in soil fertility. Waste that accumulates in river can cause and interfere the river flow, so the floods occur, for human, smoke from plastics burning waste can trigger cancer, respiratory problems, nerv-ous system disorders, and hepatitis. In this case, actu-ally plastic waste is very dangerous for human and the environment (Singh 2015).

The effort that can be done to reduce the use of conventional plastics is through the synthesizing of polymers (the raw material of polymer or plastic manufacture) that can be degraded by soil microbes. Biodegradable plastics and biobased polymer products based on renewable agricultural and biomass feedstock can form the basis for a portfolio of sustainable, eco-efficient product and that can be broken down by microbes (Vaverková et al. 2015).

Bioplastics are plastics that can be degraded and made from renewable materials so it must be biodegradable, which can include poly lactidacid, polyamide and bio-polyethylene, can be broadly described as plastics that are derived from plant material or materials that have the ability to biodegrade into natural components (Harding et al. 2017).

The cellulose contained in oil palm empty fruit bunch can also be an alternative raw material for bioplastic production. Currently, bioplastics products have been developed from oil palm empty fruit bunch (Isroi et al., 2017). Bioplastic innovations of empty palm oil bunches certainly support Indonesia Sustain-able Palm Oil (ISPO). ISPO is a standard system of sustainable palm oil plantations in Indonesia is eco-nomically viable, socially acceptable and environ-mentally friendly which is compulsory in accordance with the regulations (Septiawan et al. 2014). It also conforms to the concept Sustainable development should pay attention to 3 aspects (3P) are profit (economy), people (social) and the planet (environ-ment) (Agustina et al. 2014).

Bioplastic is designed to facilitate the degradation of enzymatic reactions of microorganisms such as bacteria and fungi. More than 90 types of microor-ganisms including: aerobes, anaerobes, photosynthet-ic bacteria, archaebacterial and lower eukaryotic are responsible for the biodegradation and catabolism of bioplastics (Emadian et al. 2017). Bioplastic pro-duced through this process must be able to be proved as biodegradable, which means it can be destroyed in certain times due to decomposition by soil microbes.

The purpose of this research is to evaluate the bio-degradability of bioplastics made from oil palm empty fruit bunch in natural environment, and compare it with biodegradability of oxodegradable plastic and conventional plastic. The biodegradation process is done on landfill soil.

\section{METHOD}

\section{Characterization of Degrading Media}

Characterization of degrading media was done by measuring C-organic. Furthermore, quantification of microorganisms was conducted by total plate count method (TPC) and $\mathrm{pH}$-media measurements were performed using $\mathrm{pH}$ meter. These measurements were done every day, starting from the 0th day up to the 45th day of the biodegradation test. The total plate count method was performed to determine the amount of bacteria present in biodegradation media. Before this process, each soil was homogenized first with aquadest at a ratio of 1:9. Subsequently, the dilu-tion was performed. At the 4th dilution, the sample was taken as much as 0.1 $\mathrm{mL}$ and poured into a petri dish containing nutrient agar (NA) solid then flattened. Incubation process lasted for $2 \times 24$ hours at $36.4{ }^{\circ} \mathrm{C}$ and followed by counting the number of colonies of microorganisms. At the time of $\mathrm{pH}$ measurement, $1 \mathrm{~g}$ sample was added with $5 \mathrm{ml}$ of water and was ho-mogenized. Prior to $\mathrm{pH}$ measurement, $\mathrm{pH}$ meter was standardized first using buffer $\mathrm{pH} 4.0$ and 7.0. Then, measurements were made by dipping the $\mathrm{pH}$ meter electrodes into the sample.

\section{Biodegradation Test by Using Respirometry Method}

The test materials used were the bioplastics made from the empty bunches of palm oil, oxodegradable plastics and conventional plastics. The landfill soil samples taken are the top soil part which has a lot of organic material content. The soils were spread onto 100 gram clock bottle. Each test plastic material weighs \pm 0.1 
gram and is placed between the piles of media, so it is expected to be evenly degraded. Calcu-lation of $\mathrm{CO} 2$ from biodegradation can be done by using a bottle arranged into biometer which is modi-fied (Reuschenbach et al. 2003; Zee 2011). The biometer used can be seen in figure 1 below.

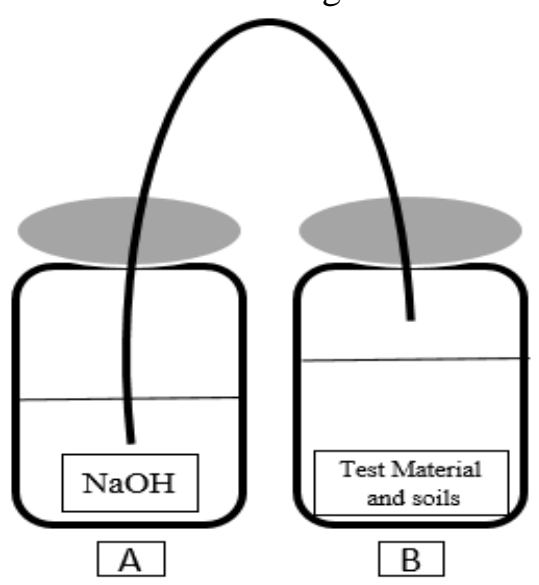

Figure 1 Handmade Biometer

Sodium hydroxide $(\mathrm{NaOH}) 0.1 \mathrm{~N}$ with a volume of $50 \mathrm{~mL}$ was placed in bottle A. During the biodegradation process, the metabolic activity of microorganisms will produce $\mathrm{CO} 2$ flowing from bottle $\mathrm{B}$ (which contains the test material and media) to bottle $\mathrm{A}$ and catch by $\mathrm{NaOH}$. The amount of reacted $\mathrm{CO} 2$ gas can be determined by titration with $0.1 \mathrm{~N}$ hydrochloric acid $(\mathrm{HCl})$ solution. Measurements of $\mathrm{CO} 2$ gas, carried out by two titration methods, first to use the phenol-phthalein (PP) indicator and titrated until the solution was colorless. Next, the process is followed by a sec-ond titration using an orange methyl indicator to a pink solution. The second titration is directly related to the $\mathrm{CO} 2$ gas present in $\mathrm{NaOH}$ solution (Syamsu et al. 2008).

\section{RESULT AND DISCUSSION}

Characterization of media was done first because environmental conditions such as medium $\mathrm{pH}$, moisture and temperature play a significant role in the de-gree of biodegradation of bioplastics (Emadian et al. 2017). Before the biodegradation process begins, the characterization of landfill soil showed initial $\mathrm{pH} 6.8$, with moisture content of $49.98 \%$ at a temperature of $28^{\circ} \mathrm{C}$. At the end of the biodegradation process, there was a change of $\mathrm{pH}$ to 8.22 with the same temperature at the beginning of $28^{\circ} \mathrm{C}$.

The initial conditions and after the biodegradation process did not give a considerable impact on the biodegradation process which is also showed in the previ-ous research related to environmental effects on biodegradability of plastic and paper (Oluwatosin et al. 2014). Organic carbon (OC) and nitrogen (N) is carbon and energy source that is important because of its association with nutrients and the beneficial contribu-tion to create all soil properties. The total values of OC and $\mathrm{N}$ greatly affect the fertility level of the soil. OC and $\mathrm{N}$ total on top soil of landfill soil were $9.57 \%$ and $1.91 \%$. According to the criteria for assessing soil qual-ity and interpreting soil test results, the value was very high and marginal respectively (GWRDC 2014). It means landfill soil was good for biodegradation process for this research.

Table 1 Quantification of Microorganisms at day 0

\begin{tabular}{cc}
\hline Sample & Total Colony at day-0 (Colony/mL) \\
\hline Blank media landfill soil as initial & $21.3 \times 10^{5}$ \\
Media containing landfill soil with bioplastic & $21.3 \times 10^{5}$ \\
Media containing landfill soil with oxodegradable plastic & $21.3 \times 10^{5}$ \\
Media containing landfill soil with conventional plastic & $21.3 \times 10^{5}$ \\
\hline
\end{tabular}


Table 2 Quantification of Microorganisms at day 45

\begin{tabular}{cc}
\hline Sample & Total Colony at day-45 (Colony/mL) \\
\hline Blank media landfill soil as initial & $5.8 \times 10^{6}$ \\
Media containing landfill soil with bioplastic & $13.3 \times 10^{6}$ \\
Media containing landfill soil with oxodegradable plastic & $7.5 \times 10^{6}$ \\
Media containing landfill soil with conventional plastic & $4.5 \times 10^{6}$ \\
\hline
\end{tabular}

The number of microorganisms at day- 0 is shown at table 1 and at day $-45^{\text {th }}$ is shown at table 2 . The total plate count method is performed to determine the amount of bacteria present in biodegradation media. The number of microorganisms from day- 0 to $45^{\text {th }}$ days increased, especially on media with bioplastic and oxodegradable plastic. Increasing number of microorganisms may be due to the existing nutrients in soil, and the material from bioplastics and oxodegradable plastic which become nutrients and food sources for microorganisms.

On the other hand, the number of microorganisms in media with conventional plastic and blank media without plastic, increased at a slower rate. The microorganisms might consume only the existing nutrients in soil since conventional plastics are mainly produced from petrol chemical elements, which do not decompose, thus resulting in environmental pollution (Singh 2015).

Figure 2 shows cumulative carbon dioxide produced (after corrected by control) by microorganisms degrading bioplastics made from oil palm empty fruit bunch, oxodegradable plastic and conventional plastic namely, $3.63 \mathrm{mg}, 2.86 \mathrm{mg}$ and $0.00 \mathrm{mg}$, respectively. The highest $\mathrm{CO}_{2}$ is produced in landfill soil containing bioplastics from oil palm empty fruit bunch, followed by landfill soil containing oxodegradable plastic. The $\mathrm{CO}_{2}$ produced by degradation of conventional plastic is more or less the same with the $\mathrm{CO}_{2}$ produced in the control (landfill soil without plastics), implying that the conventional plastics are not degraded by soil microorganisms.

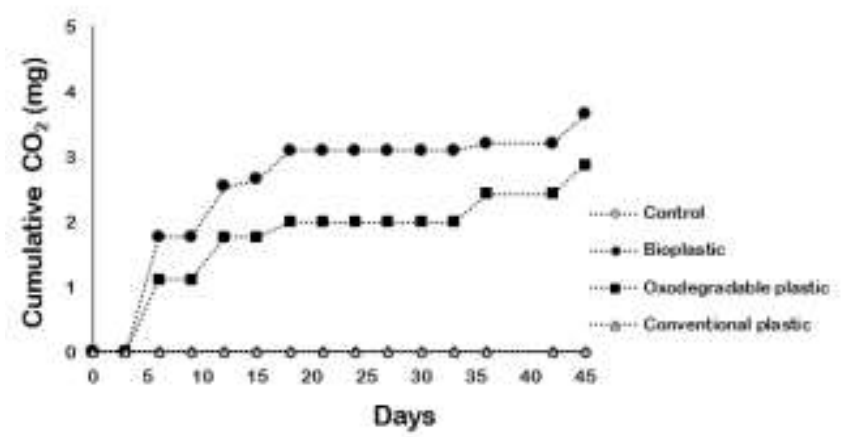

Figure 2 Cumulative $\mathrm{CO}_{2}$ production by various types of plastics in Landfill soil

Figure 2 also shows Cumulative $\mathrm{CO}_{2}$ production by various types of plastics in landfill soil in which it increases with increasing the time especially for bioplastic and oxodegradable plastic. Microorganisms decompose bioplastic from oil palm fruit bunch and oxodegradable plactic under anaerobic conditions and utilize the products of degradation as the energy and carbon source. It also stated in previous research on bioplastic degradation in natural reservoirs differing in ecological parameters using polyhydroxyalkanoates (PHAs) (Voinova et al. 2007).

Biodegradable materials such as oil palm fruit bunch and cassava starch are those that can be consumed by microorganisms whereas biodegradability of a material refers to the ability of that material to be decomposed by biological agents, especially bacteria (GWRDC 2014), cellulose and starch are food and nutrient sources for microorganisms, microbes that may break the complex molecular structure of plastics so that they can degrade and produces $\mathrm{CO}_{2}$. 
Table 3 shows rate of biodegradable in landfill soil ( $\mathrm{mg} \mathrm{CO}_{2} /$ day) by using linear regression analysis. The rate of carbon dioxide produced by bioplastics made from oil palm empty fruit bunch, oxodegradable plastic and conventional plastic were $0.067 \mathrm{mg} \mathrm{CO}_{2} /$ day, $0.052 \mathrm{mg} \mathrm{CO}_{2} /$ day and $0.000 \mathrm{mg} \mathrm{CO} /$ day, respectively.

Table 3 Rate of biodegradable in landfill soil ( $\mathrm{mg} \mathrm{CO}_{2} /$ day)

\begin{tabular}{cc}
\hline Plastics & Rate of biodegradable in landfill soil $\left(\mathrm{mg} \mathrm{CO}_{2} /\right.$ day $)$ \\
\hline Bioplastic & 0.067 \\
\hline Oxodegradable plastic & 0.052 \\
\hline Conventional plastic & 0.000 \\
\hline
\end{tabular}

Bioplastic products based on renewable agricultural and biomass feedstock can form the basis of sustainability, eco-efficient products. Respect of the environment is the most important and a special concern in a sustainable development context. We should act in this way to preserve fossil resources and reduce the pollution of the Earth.

\section{CONCLUSION}

In conclusion, it was shown that the highest $\mathrm{CO} 2$ production and the highest rate of biodegradation on landfill soil was found on bioplastic from oil palm empty fruit bunch followed by oxodegradable plastic and conventional plastic. The rates of biodegradation for bioplastic from oil palm empty fruit bunch, oxodegradable plastic and conventional plastic were $0.067,0.052$ and $0.000 \mathrm{mg} \mathrm{CO} 2 /$ day, respectively.

\section{ACKNOWLEDGEMENTS}

The authors thank to Indonesian Research Insti-tute for Biotechnology and Bioindustry, Indonesia and also thanks to Miar Trikanthi, Inten Sudiah, Vannida Masrilah Ahmad, Nurul Setiawati for their contribution in laboratory work.

\section{REFERENCES}

[GWRDC] The Grape and Wine Research and Development Corporation, 2014. Assessing Soil Quality and Interpreting Soil Test Results. Sustainable Agriculture. (3):1-8.

Agustina D, Hariyadi, Saharuddin. 2014. Socio-Economic Environmental Analysis of Sustainable Palm Oil Plantation Based on ISPO PT. Tapian Nadenggan. Journal of Natural Resources and Environmental Management. 4(1):43-48.

DiGregorio BE. 2009. Biobased Performance Bioplastic: Mirel. Chemistry and Biology. 16(1):1-2.

Emadian SM, Onay TT, Demirel B. 2017. Biodegradation of Bioplastics in Natural Environments. Waste Management. 59:526-36.

Harding KGT, Gounden, Pretorius S. 2017. Biodegradable Plastics: A Myth of Marketing. Procedia Manufacturing. 7:106-10.

Isroi A, Cifriadi, T. Panji, N.A Wibowo, K. Syamsu, 2017. Bioplastic Production from Cellulose of Oil Palm Empty Fruit Bunch. IOP Conference Series: Earth and Environmental Science. 65: 12011.

Oluwatosin OO, Alo, Moses N, Ugah, Uchenna IU, Albert MO. 2014. Environmental Effect on Biodegradability of Plastic and Paper Bags IOSR. Journal Of Environmental Science, Toxicology And Food Technology. 8(1):22-29.

Plastics Europe. 2015. Plastics - the Facts 2014/2015: An Analysis of European Plastics Production, Demand and Waste Data. PlasticsEurope. 1-34.

Reuschenbach P, Pagga U, Strotmann U. 2003. A Critical Comparison of Respirometric Biodegradation Tests Based on OECD 301 and Related Test Methods. Water Research. 37(7):1571-82. 
Septiawan H, Hariadi, Thohari M. 2014. Analysis of Environmental Management Palm Oil Mill Batu Ampar - PT SMART Tbk in the Implementation of Indonesian Sustainable Palm Oil. Journal of Natural Resources and Environmental Managemen). 4(2):136-144

Singh RV. 2015. Polyhydroxybutyrate (PHB): Biodegradable, Bioplastics Produced by Microorganisms. International Journal of Pharmaceutical Research. 7(2):17-23.

Syamsu K, Setyowati K, Khoiri AA. 2008. The Effect of Plastisizer Additions (Polyethylene Glycol 400 and Dimethyl Phtalate) on the Biodegradation Process of Bioplastics Poly-B-Hydroxyalkanoat in Liquid Media with Limited Air. Jurnal Teknologi Pertanian. 4(1): 4-14.

Vaverková, MD, Adamcová D. 2015. Biodegrability of Bioplastic Materials in a Controlled Composting Environment. Journal of Ecological Engineering. 16(3):155-60.

Voinova, ON, Kozhevnikova NA, Gladyshev MI, Volova TG. 2007. Bioplastic Degradation in Natural Reservoirs Differing in Ecological Parameters. Doklady Biological Sciences. 417(1):426-28.

Zee MVD. 2011. Analytical Methods for Monitoring Biodegradation Processes of Environmentally Degradable Polymers. Handbook of Biodegradable Polymers: Isolation, Synthesis, Characterization and Applications. 263-81 